\title{
DEVELOPMENT OF PAPUA LOCAL WISDOM BASED MATHEMATICS MODULE TO IMPROVE LEARNING OUTCOMES IN GEOMETRY TRANSFORMATION MATERIALS
}

\section{Cornely Filimdity}

SMA Negeri 9 Raja Ampat;filimditicornely@gmail.com

\begin{abstract}
This research is a development research (Research \& Development) which aims to: determine the feasibility of developing a mathematics module based on Papuan local wisdom in class XI students of SMA Negeri 9 Raja Ampat. The development of this module, the researcher refers to the ADDIE development model (Analysis, Design, Development, Implementation, and Evaluation) with an experimental design using a pre test post test one group design, which uses one research class with a sample of 24 students. The module is developed through 5 stages, namely curriculum and needs analysis, module design, module development, testing the module on a small and wide scale and evaluating the module. Material validation results obtained $92.05 \%$ and media validation results with $89.18 \%$ meaning that the module is suitable for use in learning by revising. Data analysis results using SPSS 26 for a small scale there are 15 valid questionnaire questions from 20 questions, and the average percentage is 90.21 , the reliability value is 0.935 , this shows that the questionnaire instrument has a very high level of reliability. The large-scale test for students in class XI is $91.41 \%$, meaning that this module is feasible and effective in improving learning outcomes in geometry transformation material. The $n$-Gain in the four lesson plans is 0.71 , which means that the use of mathematics modules based on Papuan local wisdom is very effective in learning.
\end{abstract}

Keywords: Module Development; Papuan Local Wisdom; Geometry Transform.

\begin{abstract}
ABSTRAK
Penelitian ini merupakan penelitian pengembangan (Research \& Development) bertujuan untuk: mengetahui kelayakan pengembangan modul matematika berbasis kearifan lokal Papua pada peserta didik kelas XI SMA Negeri 9 Raja Ampat. Pengembangan modul ini peneliti mengacu pada model pengembangan ADDIE (Analysis, Design, Development, Implementation, dan Evaluation) dengan desain eksperimen menggunakan menggunakan pre testpos test one group design, yaitu menggunakan satu kelas penelitian dengan jumlah sampel 24 peserta didik. Modul dikembangkan melalui 5 tahap yaitu analisis kurikulum dan kebutuhan, mendesain modul, pengembangan modul, menguji cobakan modul pada skalakecil dan skala luas serta evaluasi modul. Hasil validasi materi diperoleh 92,05\% dan hasil validasi media dengan $89,18 \%$ artinya modul layak digunakan dalam pembelajaran dengan merevisi. Data hasil analisis dengan menggunakan SPSS 26 untuk skala kecil terdapat 15 soal angket yang valid dari 20 soal, dan persentase rata-rata adalah 90,21, nilai nilai reliabilitas 0,935 hal ini menunjukan bahwa instrument kuesioner memiliki tingkat reliabilitas yang sangat tinggi. Uji skala besar pada peserta didik kelas XI adalah $91,41 \%$ artinya modul ini layak dan efektif dalam meningkatkan hasil belajar pada materi transformasi geometri. Perolehan $n-G a i n$ pada keempat RPP adalah 0,71 artinya penggunaan modul matematika berbasis kearifan lokal Papua sangat efektif digunakan dalam pembelajaran.
\end{abstract}

Kata kunci: Pengembangan Modul; Kearifan Lokal Papua; Transformasi Geometri. 
PENDAHULUAN

Model pembelajaran yang bervariasi sangat bergunadalam proses pembelajaran matematika. Salah satu model pembelajaran yang di perkenalkan penulis yaitu berbasis kearifan lokal Papua yang merupakan salah satu bentuk dari kebudayaan nasional Indonesia.

Kearifan lokal (local Wisdom) terdiri dari dua kata yaitu local dan wisdom. Lokal berarti setempat, sedangkan wisdom berarti kearifan. Menurut Subianto dan T Siregar (2018) hal terpenting dari kearifan lokal adalah proses sebelum implementasi tradisi pada artefak fisik, yaitu nilai-nilai dari alam untuk mengajarkan tentang bagaimana membaca potensi alam sebagai tradisi yang diterima oleh masyarakat, sebagai kearifan lokal.

Kearifan lokal Papua dan pembelajaran matematika sangat baik bila digabungkan. Kearifan lokal dapat mendekatkan matematika dengan kehidupan sehari-hari atau lingkungan dimana peserta didik tinggal (TrisnoI khwanudin, 2018). Sejalan dengan pendapat Dazrullisa (2018) dapat dimaknai bahwa pembelajaran matematika merupakan hasil kebudayaan manusia, sekaligus sebagai suatu proses untuk mengembangkan suatu kebudayaan. Salah satunya dengan menggunakan kearifan lokal sebagai suatu produk kebudayaan dalam pembelajaran matematika.
Matematika merupakan mata pelajaran ujian nasional. Hasil kelulusan peserta didik bukan dilihat berdasarkan nilai hasil kelulusan peserta didik di tentukan oleh pihak sekolah SMA Negeri 9 Raja Ampat. Masalah dalam pembelajaran matematika setiap peserta didik berbedabeda, antara lain yang ditemukan adalah kurang adanya minat belajarmatematika juga kurangnya bahan ajar matematika yang contohnya berbasis keaifan lokal. Oleh sebab itu guru hanya menggunakan buku paket yang disediakan sekolah, namun masih memiliki kekurangan, kajiannnya bersifat umum dan belum menyesuaikan dengan lingkungan belajar di daerah serta belum memuat kearifan lokal daerah. Berdasarkan alas an tersebut diperlukan suatu inovasi dalam pembelajaran. Salah satunya pengembangan modul matematika berbasis kearifan lokal Papua khususnya materi transformasi geometri guna mengatasi kesulitan penguasaan konsep dalam meningkatkan hasil belajar.

Modul sebagai salah satu alternatife bahan ajar yang dapat membantu peserta didik dalam proses pembelajaran. Modul dapat disusun sendiri oleh guru diharapkan dapat meningkatkan hasil belajar (Mardiana dan Bungkang, 2021) senada dengan penelitian Lestari dan Virman (2018) bahwa modul sangat efektif digunakan karena terdiri dari serangkaian kegiatan belajar yang disusun secara 
sistematis dengan tujuan membantu peserta didik belajar secara mandiri. Pengembangan modul matematika pada materi transformasi geometri berupa pemindahan titik, garis dan bidang disesuaikan dengan kearifan lokal Papua yang ada di lingkungan sekitar dimodifikasikan dalam modul pembelajaran dilengkapi dengan contoh soal latihan yang lebih konkrit serta Lembar Kerja Peserta Didik (LKPD).

Penelitian Subianto dan T Siregar (2018) menyatakan bahwa ada penigkatan hasil belajar kimia menggunakan modul periodik unsur berbasis kearifan lokal Papua pada setiap pertemuan. Penelitian yang sama dilakukan oleh Sri Lestari dan T Siregar (2019) memberikan kontribusi bahwa penggunaan modul IPA berbasis kearifan lokal Papua ini cukup efektif dalam meningkatkan hasil belajar peserta didik. Penelitian terkait keefektifan penggunaan media berbasis budaya Papua dalam pembelajaran penjumlahan dan pengurangan bilangan bulat ditinjau dari pretasi siswa mencapai kentutasan klasikal 77,5\% sudah melebihi Kriteria Ketuntasan Minimal KKM (M Suhadak, 2016). Untuk mengetahui kelayakan modul pembelajaran maka diperlukan pencapaian hasil belajar yang lebih maksimal sehingga penggunaan modul pembelajaran berbasis kearifan lokal sangat diperlukan disesuaikan dengan lingkungan agar peserta didik lebih mengenal kearifan local budaya di Papua. Penelitian ini bertujuan untuk menghasilkan bahan ajar berupa modul materi Transformasi Geometri berbasis kearifan Lokal Papua untuk peserta didik SMA kelas XI.

\section{METODE PENELITIAN}

Penelitian ini merupakan penelitian pengembangan Research and Development (R \& D). Produk yang dikembangkan dalam penelitian ini adalah modul matematika berbasis kearifan lokal Papua materi Transformasi Geometri. Efektivitas produk, artinya memperbaharui produk yang telah ada sehingga menjadi lebih praktis, efektif, dan efisien (Sugiyono, 2017:28)

Populasi dalam penelitian ini seluruh peserta didik pada SMA Negeri 9 Raja Ampat. Sampel dalam penelitian ini adalah peserta didik kelas XI MIPA berjumlah 12 dan kelas XI IPS berjumlah 12 peserta didik sehingga keseluruhan peserta didik kelas XI berjumlah 24 peserta didik.

Jenis penelitian ini adalah penelitian pengembangan dengan model pengembangan ADDIE, yang meliputi tahap analysis (analisis), design (perancangan), development (pengembangan), implementation (implementasi), dan evaluation (evaluasi). Control group pre test-post test designedi gunakan dalam penelitian ini. Peserta didik diberikan pretest sebelum mengikuti proses pembelajaran dan setelah seluruh 
rangkaian proses pembelajaran selesai maka di berikan post test untuk melihat peningkatan hasil belajar peserta didik dengan membandingkan nilai pretest dan post test peserta didik dengan menggunakan n-Gain.

Instrument yang digunakan dalam penelitian ini adalah instrumentes (soal pilihan ganda dan esaay) dan instrument non tes (angket). Instrument tes berupa pre test dan post tes dilakukan pada setiap RPP berupa soal pilihan ganda 10 nomor dan 5 essay untuk menguji n - Gain. Instrumen materi, dan media, divalidasi oleh dosen dan teman guru. Angket skala kecil dengan
20 pertanyaan sebelum di berikan peserta didik merupakan angket yang valid dengan mempunyai reliabitas yang tinggi .

Untuk menghitung $\mathrm{n}$-Gain menurut Sugiyono (2017) dapat digunakan dengan rumus:

$$
\mathrm{n}-\text { Gain }=\frac{S \text { post }-S \text { pre }}{S \text { maks }-S \text { pre }}
$$

\section{HASIL DAN PEMBAHASAN}

Data hasil validasi materi terdiri dari dua aspek yaitu aspek kelayakan isi dan aspek kesesuaian modul dengan pendekatan kearifan lokal Papua seperti Tabel 1

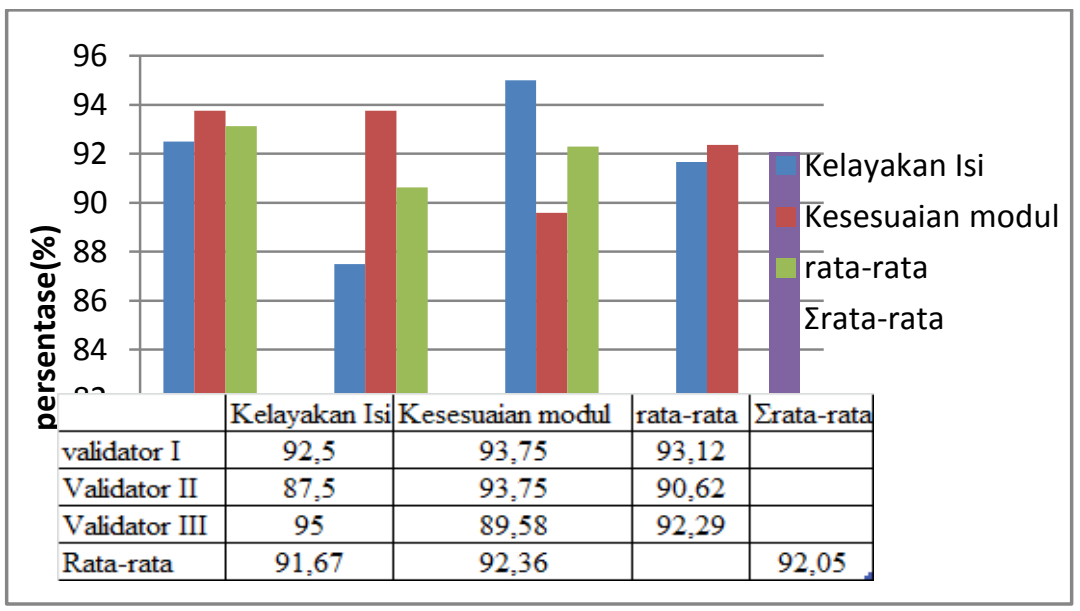

Tabel 1. Grafik Hasil Penilaian Validasi Materi

Berdasarkan Tabel 1 Grafik hasil validasi dari validator materi diperoleh sebesar 92,01\% dengan kategori sangat menarik. Beberapa yang perlu dibenahi adalah materi dalam modul disesuaikan dengan pembelajaran kontekstual berbasis kearifan lokal Papua dan soal yang dibuat harus sesuai dengan materi. Berdasarkan hasil validasi tersebut diperoleh kesimpulan bahwa modul matematika berbasis kearifan lokal Papua dengan materi tranaformasi geometri adalah modul yang menarik dan layak digunakan dalam pembelajaran, dengan merevisi beberapa bagaian.

Data hasil validasi media terdiri dari tiga aspek yang meliputi aspek kelayakan penyajian, kelayakan Bahasa dan kelayakan kegrafikan seperti Gambar 2. 


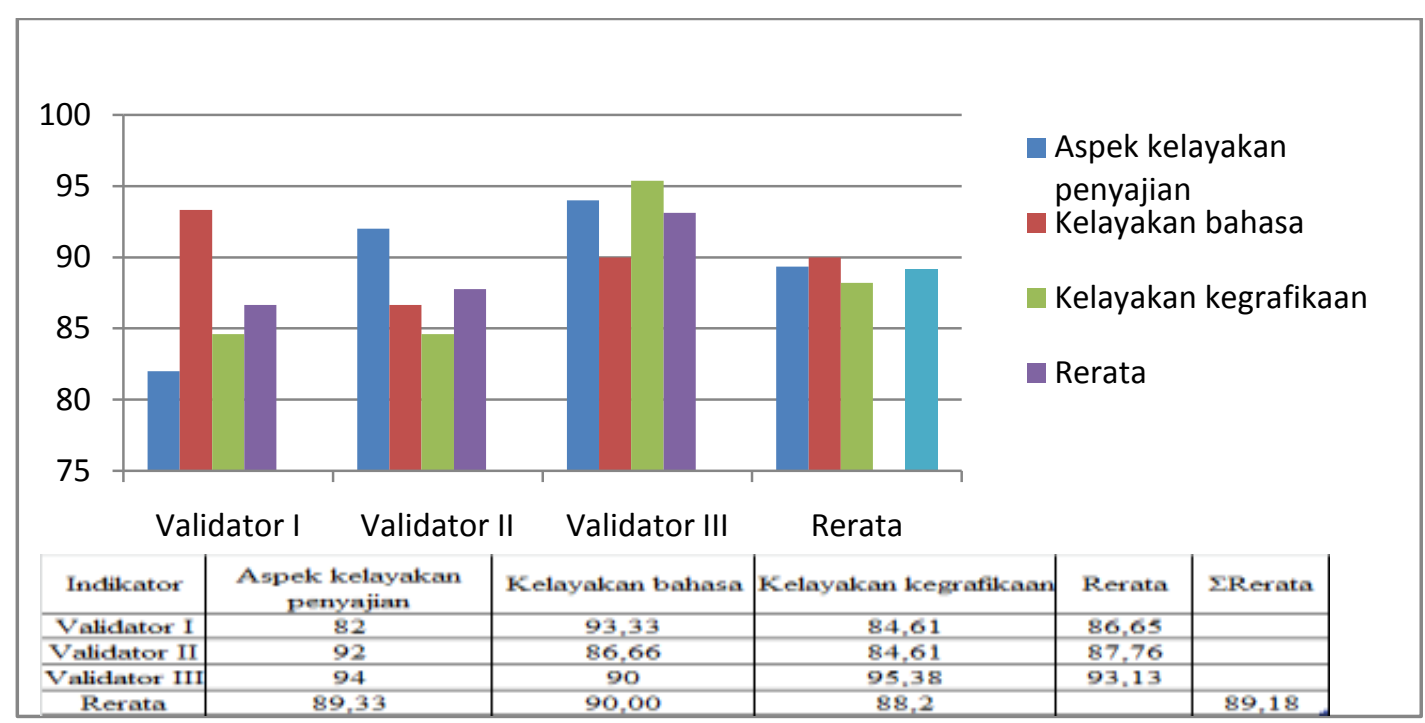

Tabel 2. Grafik Hasil Penilaian Validator Media

Hasil validasi (Tabel 2) oleh validator media diperoleh sebesar $89,18 \%$ dengan kategori menarik dan layak digunakan pada materi transformasi geometri. Senada dengan pendapat Neneng, dkk (2020) bahwa uji kelayakan berdasarkan penilaian validator menunjukan bahwa bahan ajar matematika berbasis kearifan lokal berkategori sangat baik sehingga bahan ajar layak digunakan.

Tanggapan guru mengenai modul yang setelah diberikan angket kepada dua orang guru matematika yang mengajar di kelas X dan kelas XII dapat dilihat pada Tabel 3 sebagai berikut:

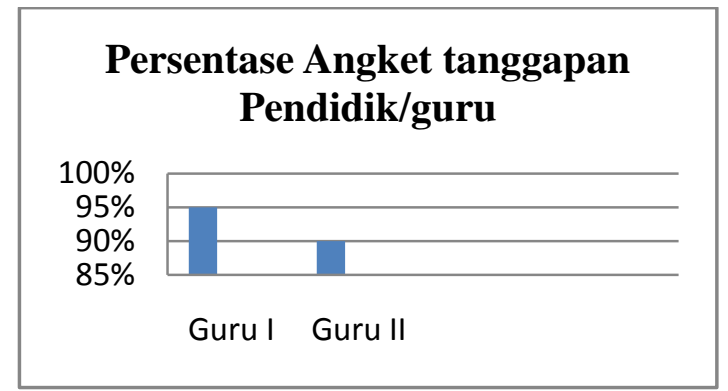

Tabel 3. Grafik Hasil Tanggapan Guru
Rerata persentase, hasil tanggapan guru berkisar sebesar 93\%, artinya sangat setuju dengan adanya modul matematika pada materi transformasi geometri berbasis kearifan lokal papua ini, kemudian diujicobakan pada kelompok kecil yang diwakili oleh 6 orang responden yang diambil secara acak dari kelas XII yaitu 3 orang dari kelas XII MIPA dan 3 orang dari kelas XII IPS. Langkah- langkah yang dilakukan dalam uji coba skala kecil ini adalah persyaratan mengisi angket tanggapan peserta didik. Angket yang diberikan tersebut diuji validitas dan reliabilitas dengan menggunakan SPSS 26, setelah soal tersebut valid, kemudian diuji reliabilitasnya, dengan membandingkan nilai Cronbach's Alpha sebesar 0,935 dan lebih besar dari cronbach alpha 0,6 maka disimpulkan angket tersebut reliabel, kemudian angket yang valid diberikan kepada responden pada uji coba skala kecil 
(Small Group Evaluation) dapat dilihat pada Gambar 4:

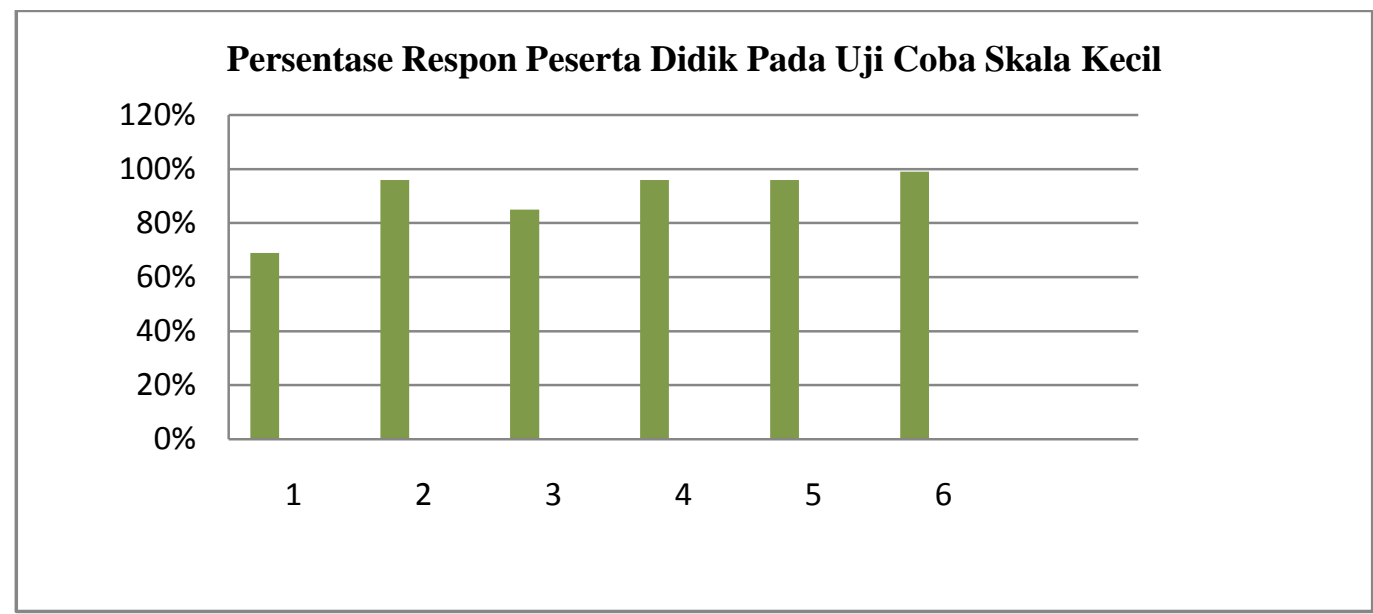

Tabel 4.Grafik Respon Peserta Didik pada Uji Coba Skala Kecil (Small Group Evaluation)

Pengisian angket pada uji coba skala kecil terhadap modul matematika berbasis kearifan lokal Papua, maka persentase tingkat pencapaian modul Matematika adalah 90,20\% artinya (Tabel 4) tingkat kriteria sangat menarik Setelah modul diujicoba pada skala kecil, maka selanjutnya dilakukan ujicoba pada skala besar, yaitu memberikan angket pada 24 orang peserta didik di kelas XI SMA Negeri 9 Raja Ampat. Berdasarkan hasil uji coba skala besar terhadap modul matematika pada materi transformasi geometri berbasis kearifan lokal Papua maka dapat dihitung persentase tingkat pencapaian $91,41 \%$ artinya tingkat kriteria sangat menarik, maka modul yang dikembangkan ini sangat layak dan sangat efektif untuk digunakan sebagai bahan ajar. Hal ini sesuai pendapat Neneng, dkk (2020) mengatakan bahwa uji kelayakan berdasarkan angket respon peserta didik menunjukan bahwa bahan ajar matematika berbasis kearifan lokal memperoleh kategori sangat baik dengan persentase $81 \%$ sehingga bahan ajar matematika berbasis kearifan lokal sangat layak digunakan. Hasil dari validator materi, validator media, angket guru, uji coba skala kecil dan uji coba skala besar diperoleh rerata untuk kelayakan modul sebesar $91,02 \%$ yang berarti modul layak digunakan dalam pembelajaran matematika wajib Rahayu dkk (2020).

Nilai n-Gain hasil belajar matematika pada materi transformasi geometri dari RPP -1 RPP ditunjukkan Tabel 1 sebagai berikut: 
Tabel 1. Hasil Belajar pada RPP 1 s/d RPP 4.

\begin{tabular}{|c|c|c|c|c|c|}
\hline Pertemuan & Kategori & Jumlah & Persentase & $\begin{array}{l}\text { n-Gain } \\
\text { Rerata }\end{array}$ & $\begin{array}{l}\text { Tingkat } \\
\text { e fektifitas }\end{array}$ \\
\hline \multirow{3}{*}{ RPP 1} & Rendah & 1 & $4 \%$ & \multirow{3}{*}{0,78} & \multirow{3}{*}{ Tinggi } \\
\hline & Sedang & 6 & $25 \%$ & & \\
\hline & Tinggi & 17 & $71 \%$ & & \\
\hline \multirow[t]{3}{*}{ RPP 2} & Rendah & 3 & $12 \%$ & \multirow[t]{3}{*}{0,62} & \multirow[t]{3}{*}{ Sedang } \\
\hline & Sedang & 11 & $46 \%$ & & \\
\hline & Tinggi & 10 & $42 \%$ & & \\
\hline \multirow[t]{3}{*}{ RPP 3} & Rendah & 3 & $12 \%$ & \multirow[t]{3}{*}{0,65} & \multirow[t]{3}{*}{ Sedang } \\
\hline & Sedang & 10 & $42 \%$ & & \\
\hline & Tinggi & 11 & $46 \%$ & & \\
\hline \multirow[t]{3}{*}{ RPP 4} & Rendah & 0 & $0 \%$ & \multirow[t]{3}{*}{0,78} & \multirow[t]{3}{*}{ Tinggi } \\
\hline & Sedang & 11 & $46 \%$ & & \\
\hline & Tinggi & 13 & $54 \%$ & & \\
\hline \multicolumn{4}{|c|}{ Rerata } & 0,71 & Tinggi \\
\hline
\end{tabular}

Uji n-Gain (Tabel 1) diperoleh hasil rerata n-Gain pada RPP - 1 adalah 0,78 , materi translasi, RPP - 2 sebesar 0,62, materi refleksi, RPP - 3 sebesar 0,65, materi rotasi, dan RPP - 4 sebesar 0,78, materi dilatasi. Rerata total n-Gain adalah 0,71 dengan kategori tnggi dan efektif digunakan untuk meningkatkan hasil belajar matematika pada materi transformasi geometri peserta didik kelas XI SMA Negeri 9 Raja Ampat.

\section{SIMPULAN DAN SARAN SIMPULAN}

Peningkatan hasil belajar peserta didik dengan menggunakan modul matematika pada materi transformasi geometri berbasis kearifan lokal Papua dari RPP-1 hingga RPP-4 diperoleh nilai nGain rerata pre test dan post test yaitu 0,71 dengan kategori tinggi yang berarti penggunaan modul sangat efektif dalam peningkatan hasil belajar peserta didik kelas XI SMA Negeri 9 Raja Ampat.

\section{SARAN}

Modul matematika pada materi transformasi geometri berbasis kearifan lokal Papua selain pokok bahasan transformasi geometri perlu dikembangkan untuk meningkatkan hasil belajar peserta didik.

\section{UCAPAN TERIMA KASIH}

Terimakasih kepada Kepala Sekolah SMA Negeri 9 Raja Ampat dan kepada ketua program studi S2 Magister Pendidikan IPA FKIP Universitas Cenderawasih telah mengadakan kerjasama dalam penelitian dalam penelitian ini.

\section{DAFTAR PUSTAKA}

Dazrullisa (2018). Pengaruh Pembelajaran Matematika berbasis Kearifan Local Terhadap Minat Belajar Siswa, Genta Mulia ,Vol IX No.2 .h 141 149;

Farhatin, N, Pujiastuti, H,Mutaqin, A, (2020). "Pengembangan Bahan Ajar Matematika Berbasis Kearifan Lokal Untuk Siswa Smp Kelas VIII "Prima: Jurnal Pendidikan Matematika Vol. 4, No. 1, Januari 2020, hal. 33-45; 
Ikhwanudin, T. (2018). Pembelajaran Matematika Berbasis Kearifan Lokal Untuk Membangun Karakter Bangsa.UNION; Jurnal Pendidikan Matematika UPI Vol 6 No.1 Maret 2018;

Lestari, R. E. dan Virman (2018). Pengembangan Modul Pembelajaran Fisika Berbasis discovery Learning pada materi vector peserta didik kelasX SMA KPG Khas "Papua" Merauke;

Mardiana dan Bungkang, Y.(2021). Pengembangan Modul Fisika Berbasis kontekstual materi dinamika partikel : Jayapura, Jurnal Ilmu Pendidikan Indonesia, $\mathrm{Vol}$ 9,N0.1 hal 44 - 52 ,Februari 2021;

Rahayu, P.,Rumahorbo, B. T.,Wahyudi, I. (2020). Pengembangan Modul IPA berbasis discovery leaning dalam meningkatkan, keterampilan proses, peserta didik pada materi getaran ,gelombang dan bunyi; Jurnal Ilmu Pendidikan Indonesia, Vol 8 No.2 Hal 95 - 102 Juni 2020;

Siregar,S. (2017). Metode Penelitian Kuantitatif. Jakarta : Kencana Prenada media Group;
Sri Lestari, Siregar, T. dan Nainggolan, J. (2019). Pengembangan Modul IPA terpadu berbasis kearifan lokal Papua materi Interaksi mahluk Hidup dengan Lingkungan pada peserta didik kelas VII SMP Nurul Huda Yapis Jayapura.; jurnal ilmu pendidikan Indonesia vol 7 No. 3 hal. 106 -1112;

Subiyanto dan Siregar, T.(2018). Pengembangan Modul Pembelajaran Kimia pada materi Sistem Periodik Unsur Berbasis kearifan Lokal Papua Peserta Didik kelas X SMA Negeri 4 :Jayapura, Jurnal Ilmu Pendidkan Indonesia , Vol 6. No.3,November 2018, hal $71-82$;

Sugiyono, (2017). Metodelogi Penelitian Kuantitatif, Kualitatif dan $R \& D$. Bandung: Alfabeta.

Suhadak, M.(2016). Keefektifan Penggunaan Media berbasis Budaya Papua dalam pembelajaran penjumlahan dan pengurangan bilangan bulat ditinjau dari prestasi; Indonesian Digital Journal of Mathematics and Education Vol 3 No.4 tahun 2016 ; 